Tạp chí Khoa học và Công nghệ biển T10 (2010). Số 1. Tr 51 - 65

\title{
MỘT SỐ KẾT QUẢ NGHIÊN CÚU VỀ VI SINH VẠT TẠI VÙNG VEN BIỂN HẢI PHÒNG
}

\author{
ĐỖ MẠNH HÀO, PHẠM THẾ THU \\ Viện Tài nguyên và Môi trường biển
}

\begin{abstract}
Tóm tắt: Tù̀ 50 mẫu nuớc và trầm tích vùng ven biển Hải Phòng đã phân lập được 65 chủng vi khuẩn điển hình thuộc 31 loài, 16 chi, 8 ho và 2 bộ. Số luợng nhóm vi khuẩn hiếu khí rù̀ng ngập mặn Bàng La, Tràng Cát khá cao, biến động $10^{4}-10^{7}$ tb/ml,g; xạ khuẩn tì 0 $10^{2} \mathrm{tb} / \mathrm{ml}, \mathrm{g}$; nấm men tù̀ $0-2.10^{2} \mathrm{tb} / \mathrm{ml}$, g và nấm sợi có mật độ đạt tới $10^{3} \mathrm{tb} / \mathrm{ml}$, g. Số lương vi khuẩn hiếu khi và xạ khuẩn trong các mẫu trầm tích thuờng cao hơn mẫu nước bề mặt tù 10 100 lần, nhung nấm sợi và nấm men lại có xu huớng ngược lại, đặc biệt vào mùa mua. Nhiều chủng vi khuẩn có hoạt tính nitrat hoá, phản nitrat, phân giải protein, tinh bột và khả năng đối kháng với vi khuẩn gây bệnh Vibrio parahaemolyticus và Vibrio fuoniss cao. Chế phẩm dạng lỏng và bột được tạo ra tù tổ hợp một số chủng vi khuẩn trên khi thử nghiệm trên nước thải đầm nuôi trồng thuỷ sản cho thấy các chỉ tiêu môi truờng được phân tích là $D O, C O D$, $\mathrm{BOD}_{5}$ và $\mathrm{NH}_{4}{ }^{+}$có sụ cải thiện đáng kể so với mẫu đối chứng sau 10 ngày thả chế phẩm.
\end{abstract}

Tù̀ khoá: vi khuẩn hiếu khi; xạ khuẩn, nấm men; nấm sợi; rù̀ng ngập mặn Bàng La và Tràng Cát; chế phẩm dạng lỏng và dạng bột.

\section{MỞ ĐÀ̀U}

Vùng ven biển Hải Phòng nằm trong phạm vi hệ tọa độ $20^{0} 35^{\prime} 00^{\prime \prime}-21^{0} 00^{\prime} 00^{\prime} \mathrm{N}$ và $106^{0} 35^{\prime} 00^{\prime}-107^{0} 10^{\prime} 40^{\prime}$ 'E, phía Đông và Đông Bắc giáp với ven biển Quảng Ninh, phía Tây và Nam giáp với vùng ven biển Thái Bình. Trong đó, Vùng này bao gồm đới ngập triều rộng $242 \mathrm{~km}^{2}$ và đới bờ ngầm với độ sâu $6-10 \mathrm{~m}$ rộng trên $500 \mathrm{~km}^{2}$ [8] đã tạo ra nhiều kiểu hệ sinh thái khác nhau như là rừng ngập mặn (RNM), cửa sông, bãi triều cát, khu vực nuôi trồng thuỷ sản và cảng biển. Vùng ven biển này nằm trong khu vực nhiệt đới gió mùa với mùa mưa nóng ẩm mưa nhiều và mùa khô lạnh khô ít mưa, các thông số trầm tích lơ lửng, độ muối, pH, nhiệt độ và các hợp chất hữu cơ hoà tan cũng có sự biến đổi theo mùa rất rõ rệt.

Cho đến nay, đã có nhiều công trình nghiên cứu về đa dạng của hệ thống động thực vật, đánh giá nguồn lợi thuỷ sản và các điều kiện thuỷ lý, thuỷ hoá, nhưng vẫn còn thiếu những nghiên cứu về vi sinh vật (VSV), nhóm sinh vật đóng vai trò rất quan trọng trong 
quá trình chuyển hoá vật chất, đồng thời vi sinh vật cũng là nguồn gen giá trị cho các ngành công nghiệp thực phẩm, $\mathrm{y}$ dược, hoá mỹ phẩm và xử lý môi trường. Chính vì vậy, chúng tôi đã tiến hành nghiên cứu sự đa dạng vi sinh vật, đồng thời đánh giá và tuyển chọn một số chủng vi sinh vật hữu ích tại khu vực này.

\section{PHƯƠNG PHÁP NGHIÊN CÚU}

\section{Nguyên liệu}

Bao gồm 50 mẫu nước và trầm tích được thu thập tại các đầm nuôi trồng thuỷ sản, rừng ngập mặn, cửa sông trong vùng ven biển Hải phòng, thuộc đề tài cơ sở Viện Tài nguyên và Môi trường biển những năm 2003, 2004, 2005 và 2007.

\section{Phương pháp}

\subsection{Thu mẫu ngoài hiện trường}

- Mẫu nước được lấy bằng bathometer sau đó chuyển vào lọ thuỷ tinh dung tích 100 $\mathrm{ml}$ đã khử trùng và bảo quản lạnh trong hộp xốp có chứa đá trước khi mang về phòng thí nghiệm phân tích.

- Mẫu trầm tích được lấy bằng thiết bị lấy bùn chuyên dụng hoặc bằng thìa inox đã khử trùng, khoảng $500 \mathrm{~g}$ trầm tích được chuyển vào túi nylon và bảo quản lạnh trong hộp xốp có chứa đá trước khi mang về phòng thí nghiệm phân tích.

\subsection{Phương pháp trong phòng thí nghiệm}

- Đếm số lượng các vi sinh vật và phân lập vi sinh vật hữu ích trên môi trường chọn lọc: Vi khuẩn hiếu khí (HK) trên môi trường hiếu khí tổng số; Nấm men (NMn) trên môi trường Hansen; Nấm mốc $(\mathrm{NM})$ trên môi trường Czapek; Xạ khuẩn $(\mathrm{XK})$ trên môi trường xạ khuẩn biển (1).

- Xác định hình dạng tế bào dưới kính hiển vi thường (Ba Lan) và kính hiển vi điện tử quét JSM-5410 LV, JEOL (Nhật Bản) (1).

- Xác định các đặc điểm sinh lý và sinh hoá của vi khuẩn theo hướng dẫn của Smibert \& Krieg, (1994) (10).

- Đoạn gen 16S rRNA sau khi được nhân lên và thuần khiết sẽ được đọc trực tiếp trên máy đọc gen ABI 3100.

- Phân loại vi khuẩn theo khoá phân loại của Bergey, (1957) (9).

- Xác định hàm lượng amoni $\left(\mathrm{NH}_{3}\right)$ và nitrit $\left(\mathrm{NO}_{2}{ }^{-}\right)$trong nước biển được xác định bằng phương pháp so màu phenat trên máy đo quang phổ kế DR/2000 $(\mathrm{HACH}, \mathrm{Mỹ})$ với dài đo: từ vết $(0,0 \mu \mathrm{gN})$ trở lên, độ phân giải: $0,1 \mu \mathrm{gN}$ và sai số: $\pm 10 \%$ giá trị đo. 


\section{KẾT QUẢ NGHIÊN CÚU}

\section{Thành phần loài}

Bảng 1: Thành phần loài các chủng vi khuẩn phân lập từ ven biển Hải Phòng

\begin{tabular}{|c|c|c|c|}
\hline Stt & Thành phần loài & Stt & Thành phân loài \\
\hline & Class: Schizomycetes & & Family VI: Bacteroidaceae \\
\hline & Order I: Pseudomonadales & & Genus 8: Bacteroides \\
\hline & Sub-order: Rhodobacteriineae & 13 & Bacteroides capillosus \\
\hline & Family I: Nitrobacteriaceae & & Genus 9: Streptobacillus \\
\hline & Genus 1: Nitrosomonas & 14 & Streptobacillus moniliformis 2VK2 \\
\hline \multirow[t]{2}{*}{1} & Nitrosomonas spp. & 15 & Streptobacillus moniliformis $1 \mathrm{VK} 3$ \\
\hline & Genus 2: Nitrobacter & & Family VII: Achromobacteraceae \\
\hline \multirow[t]{2}{*}{2} & Nitrobacter spp. & & Genus 10: Alcaligenes \\
\hline & Genus 3: Nitrospina & 16 & Alcaligenes faecalis \\
\hline \multirow[t]{3}{*}{3} & Nitrospina spp. & & Genus 11: Flavobacterium \\
\hline & Family II: Athiorhodaceae & 17 & Flavobacterium marinum \\
\hline & Genus 4: Rhodopseudomonas & 18 & Flavobacterium marinotypicum \\
\hline 4 & $\begin{array}{l}\text { Rhodopseudomonas capsulate } \\
\text { BLV-01 }\end{array}$ & & Genus 12: Achromobacter \\
\hline \multirow[t]{4}{*}{5} & $\begin{array}{l}\text { Rhodopseudomonas capsulate } \\
\text { BLV-02 }\end{array}$ & 19 & Achromobacter liquefaciens \\
\hline & Sub-order: Pseudomonadineae & & Genus 13: Lactobacillus \\
\hline & Family III: Pseudomonas & 20 & Lactobacillus spp. \\
\hline & Genus 5: Pseudomonas & & Genus 14: Escherichia \\
\hline 6 & Pseudomonas aeruginosa & 21 & Escherichia sp. \\
\hline 7 & Pseudomonas pseudomallei & & Genus 15: Bacillus \\
\hline 8 & Pseudomonas caviae & 22 & Bacillus subtilus STCK99 \\
\hline 9 & Pseudomonas fluorescens & 23 & Bacillus subtilus VK07 \\
\hline \multirow[t]{4}{*}{10} & Pseudomonas putida & 24 & Bacillus lichenniformis \\
\hline & Order II: Enbacteriales & 25 & Bacillus cereus \\
\hline & Family IV: Rhizobaiceae & 26 & Bacillus brevis \\
\hline & Genus 6: Rhizobium & 27 & Bacillus megaterium \\
\hline \multirow[t]{3}{*}{11} & Rhizobium spp. 2 V2 & 28 & Bacillus sphaericus \\
\hline & Family V: Brevibacteraceae & 29 & Bacillus spp. 2VK5 \\
\hline & Genus 7: Brevibacterium & 30 & Bacillus spp. 2V8 \\
\hline \multirow[t]{3}{*}{12} & Brevibacterium healii & & Family VIII: Bacillaceae \\
\hline & & & Genus 16: Clostridium \\
\hline & & 31 & Clostridium spp. 2V1 \\
\hline
\end{tabular}


Dựa trên các đặc điểm hình thái khuẩn lạc, tế bào, đặc điểm sinh lý, sinh hoá, kết quả giải trình tự $16 \mathrm{~S}$ rRNA và theo khóa phân loại của Bergey's 1954. Chúng tôi xếp 65 chủng vi khuẩn phân lập được từ vùng ven biển Hải Phòng vào 31 loài, 16 chi, 8 họ, 2 bộ (bảng 1). Tất cả các chủng giống này đã được lưu vào bộ sưu tập giống vi sinh vật của Viện.

Họ Achromobacteraceae có số chi nhiều nhất - 6 chi, trong khi đó các họ khác chỉ có từ $1-2$ chi. Chi Bacillus có tới 8 loài vi khuẩn khác nhau, tiếp đến là chi Pseudomonas với 5 loài vi khuẩn, các chi còn lại chỉ có từ 1 - 2 loài.

\section{Phân bố của VSV trong RNM Bàng La và Tràng Cát}

Kết quả cho thấy cả 4 nhóm vi sinh vật này đều có mặt ở trong vùng nghiên cứu với mật độ khác nhau (bảng 2):

Số lượng tế bào vi khuẩn hiếu khí biến động từ $10^{4}-10^{7} \mathrm{tb} / \mathrm{ml}$; g, mật độ tế bào vi khuẩn hiếu khí ít nhất trong mẫu nước Bàng La vào mùa khô - $10^{4}$ và cao nhất là mẫu đất Tràng Cát vào mùa mưa $-10^{7}$ (hình 1 ).

Số lượng xạ khuẩn đạt mật độ cực đại là $10^{2} \mathrm{tb} / \mathrm{ml} ; \mathrm{g}$ trong mẫu đất Tràng Cát vào mùa mưa. Số lượng tế bào nấm men đạt mật độ cao nhất trong mẫu nước Tràng cát vào mùa mưa $-2.10^{2} \mathrm{tb} / \mathrm{ml} ; \mathrm{g}$, nấm men không thấy xuất hiện trong tất cả các mẫu vào mùa khô. Trong mẫu nước Tràng Cát vào mùa mưa mật độ tế bào nấm sợi đạt tới $10^{3} \mathrm{tb} / \mathrm{ml} ; \mathrm{g}$, nhiều mẫu không thấy có mặt nấm sợi (hình 2).

Bảng 2: Số lượng một số nhóm vi sinh vật trong RNM Bàng La - Tràng Cát

\begin{tabular}{|l|r|r|r|r|r|r|r|r|}
\hline & \multicolumn{4}{|c|}{ Mùa mura (tháng 8/2007) } & \multicolumn{4}{|c|}{ Mùa khô (3/2008) } \\
\cline { 2 - 10 } & HK & \multicolumn{1}{|c|}{ XK } & NM & \multicolumn{1}{l|}{ NS } & HK & \multicolumn{1}{l|}{ XK } & NM & \multicolumn{1}{l|}{ NS } \\
\hline STC & $10^{7}$ & $10^{2}$ & 15 & 50 & $10^{6}$ & $10^{2}$ & 0 & 0 \\
\hline WTC & $10^{6}$ & 0 & $2 \times 10^{2}$ & $10^{3}$ & $5 \times 10^{4}$ & 0 & 0 & 50 \\
\hline SBL & $10^{7}$ & $10^{1}$ & 0 & 0 & $10^{6}$ & 10 & 0 & 0 \\
\hline WBL & $10^{5}$ & 0 & 10 & $2 \times 10^{2}$ & $10^{4}$ & 0 & 0 & 0 \\
\hline
\end{tabular}

Ghi chú: STC: Đất RNM Tràng Cát, WTC: Nước RNM Tràng Cát, SBL: Đất RNM Bàng La, WBL: Nước RNM Bàng La, HK: Vi khuẩn hiếu khí, XK: Xạ khuẩn, NM: nấm men, NS: nấm sợi

Nhìn chung, tế bào vi khuẩn hiếu khí, xạ khuẩn, nấm men hay nấm sợi đều có mật độ cao vào mùa mưa và có mật độ thấp hơn nhiều vào mùa khô. Đặc biệt là nấm men và 
nấm sợi, chúng hầu như không có mặt trong các mẫu vào mùa khô. Có thể vào mùa mưa, nước từ các lưu vực sông mang theo một lượng lớn nguồn dinh dưỡng và cả các vi sinh vật lục địa phân tán vào vùng RNM này làm cho khu hệ VSV ở đây phong phú thêm.

RNM Tràng Cát có số lượng VSV cả 4 nhóm vi khuẩn hiếu khí, xạ khuẩn, nấm men, nấm sợi đều cao hơn VSV ở RNM Bàng La. Đây có thể là kết quả của sự khác nhau về thành phần môi trường từ 2 RNM này.

Các mẫu nước có số lượng nấm men và nấm sợi cao hơn các mẫu trầm tích, điều này có thể lý giải là do 2 nhóm VSV này có thể di nhập tạm thời từ các vùng lục địa ra.

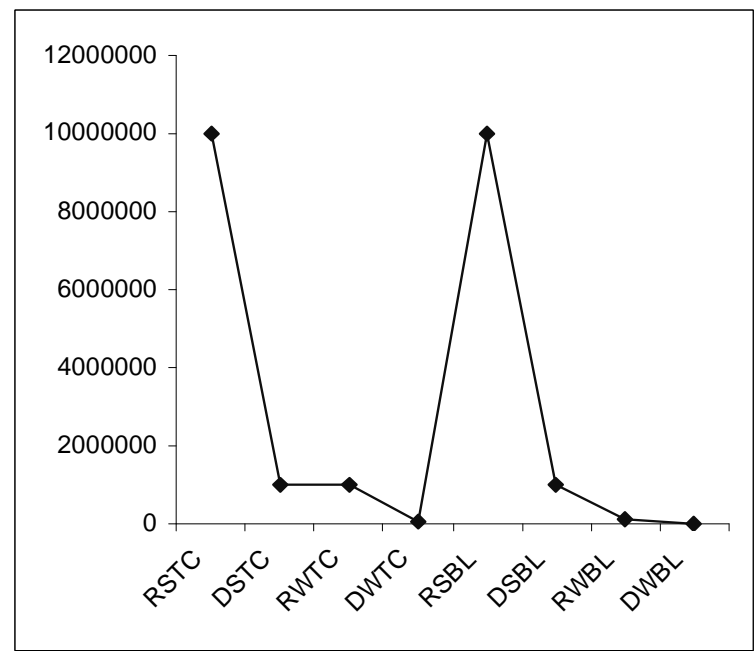

Hình 1: Phân bố vi khuẩn HK trong RNM Tràng Cát và Bàng La mùa mưa $(\mathrm{R})$ và khô (n)

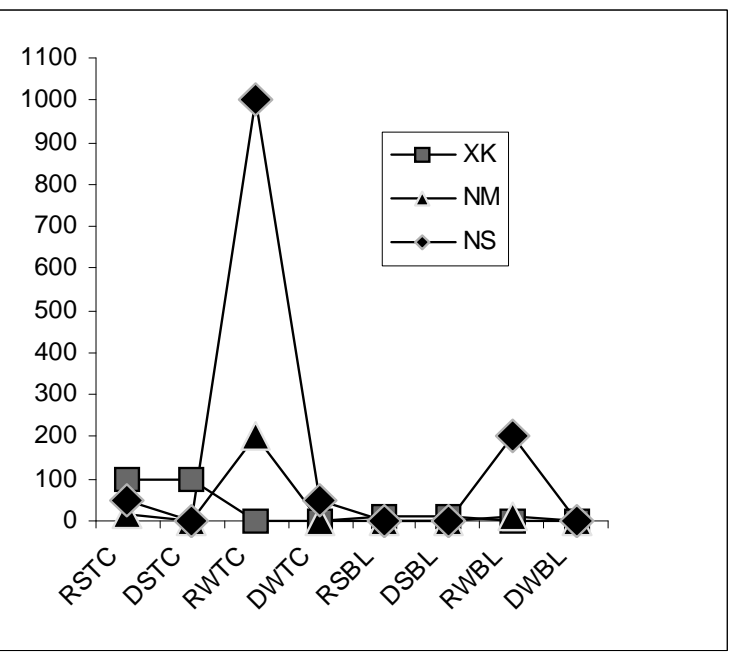

Hình 2: Phân bố XK, NM và NS trong RNM Tràng Cát và Bàng La mùa mưa $(\mathrm{R})$

\section{3. Đặc điểm hình thái}

Từ khoảng 50 mẫu trầm tích và nước vùng ven biển Hải phòng, chúng tôi tuyển chọn được 65 chủng vi khuẩn khác nhau (bảng 3). Các khuẩn lạc có màu sắc rất khác nhau, từ màu trắng sữa, màu đất đến màu vàng, lục và màu đỏ. Hình dạng và kích thước khuẩn lạc cũng khá đa dạng, có những khuẩn lạc có kích thước từ nhỏ đến to và lan toả lên khắp bề mặt thạch, mép khuẩn lạc có thể tròn đều đến răng cưa, bề mặt lồi hoặc lõm.

Đa số các chủng phân lập được có tế bào dạng hình que ngắn đến dài, cũng có mặt các tế bào có dạng hình cầu, xoắn và hình ovan, một số chủng có dạng đa hình và biến đổi theo chu kì phát triển hay điều kiện môi trường. Các chủng này có thể phản ứng âm hay dương khi nhuộm Gram. 


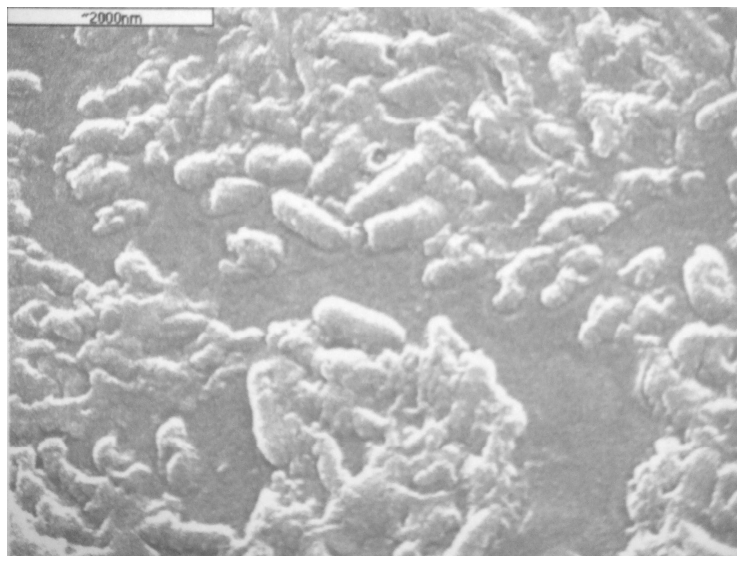

A. Chủng vi khuẩn PLTa

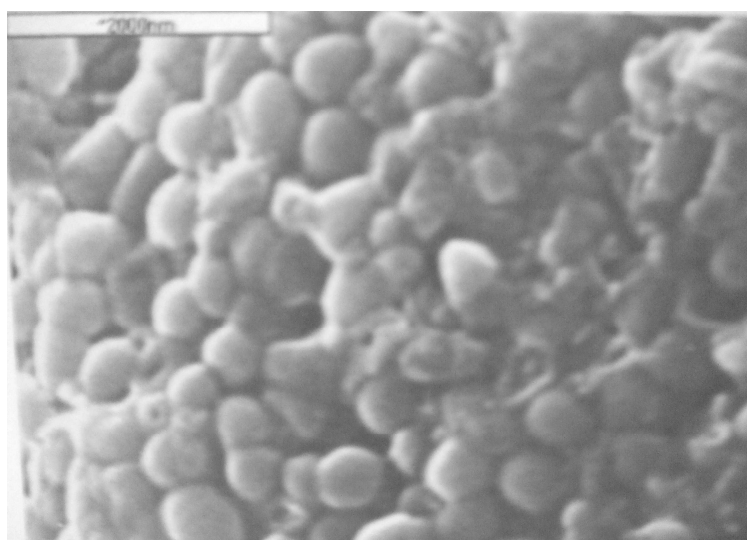

C. Chủng vi khuẩn PLTE

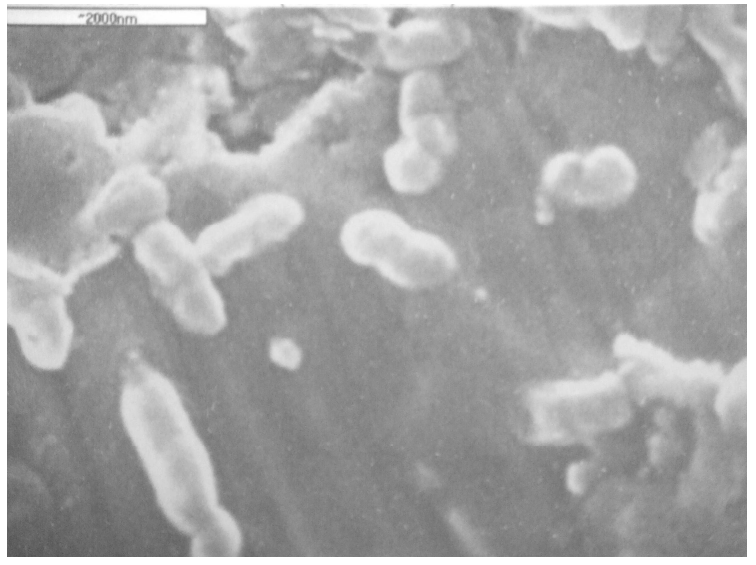

B. Chủng vi khuẩn PLTb'

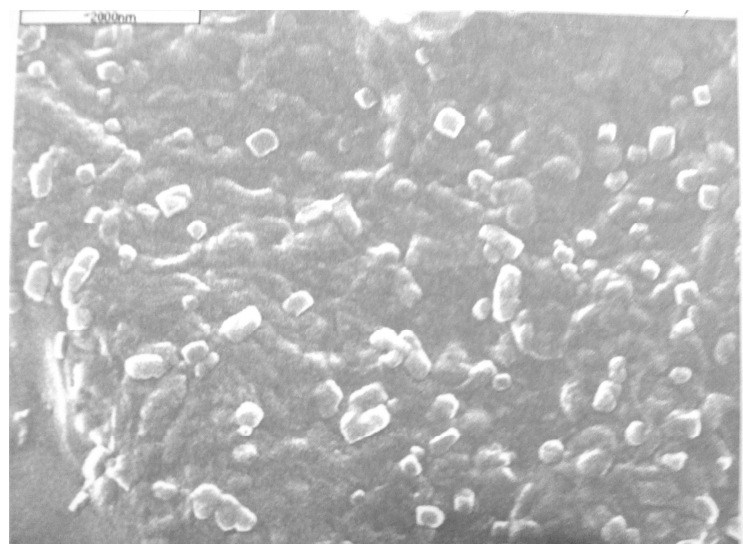

D. Chủng vi khuẩn KT8c

Hình 3: Ảnh tế bào một số chủng vi khuẩn dưới kính hiển vi điển tử quét

\section{4. Đặc điểm sinh lý}

Các chủng vi khuẩn nghiên cứu được phân tích khả năng phản ứng với oxy, với nhiệt độ tại $4,30,45$ và $55^{\circ} \mathrm{C}$, phản ứng với nồng độ muối tại 10 nồng độ khác nhau từ $0 \%$ đến $10 \%$, và ba $\mathrm{pH}$ khác nhau là 5,$5 ; 7,0$ và 9,5 .

Hầu hết các chủng vi khuẩn được phân lập là vi khuẩn vi hiếu khí đến hiếu khí. Chúng đều là những vi khuẩn chịu muối và sinh trưởng tốt nhất tại nồng độ muối từ 2 $3 \%$. Chúng có khả năng sinh trưởng tốt nhất tại $30^{\circ} \mathrm{C}$, một số chủng có khả năng sinh trưởng tại $45^{\circ} \mathrm{C}$, nhưng những chủng vi khuẩn này không mọc được tại $4^{0} \mathrm{C}$ và $55^{\circ} \mathrm{C}$. Giới hạn $\mathrm{pH}$ của các chủng vi khuẩn này khá rộng, từ 5,5 đến 9,5 , tuy nhiên chúng có khả năng sinh trưởng tốt hơn tại các pH kiềm. 
Bảng 3: Đặc điểm hình thái một số chủng vi khuẩn điểm hình

\begin{tabular}{|c|c|c|c|c|}
\hline \multirow[t]{2}{*}{ Mẫu } & \multirow[t]{2}{*}{ Chủng } & \multirow[t]{2}{*}{ Đặc điểm khuẩn lạc } & \multicolumn{2}{|c|}{$\begin{array}{l}\text { Đặc điểm } \\
\text { tế bào }\end{array}$} \\
\hline & & & H. thái & Gram \\
\hline Đầm nuôi Kiến Thuỵ & KT1a & Tròn nhỏ li ty, màu sữa & Cầu & - \\
\hline Đầm nuôi Kiến Thuỵ & KT8a' & Khuẩn lạc tròn màu lục, bề mặt nhẵn & Que & - \\
\hline Đầm nuôi Đồ Sơn & ĐS1a' & $\begin{array}{l}\text { Khuẩn lạc tròn, màu vàng bề mặt } \\
\text { nhẵn }\end{array}$ & Que & - \\
\hline Đầm nuôi Đồ Sơn & ĐS1c & Khuẩn lạc nhỏ li ty, màu vàng & Que & - \\
\hline RNM Gia Minh & GMTa & Khuẩn lạc tròn, màu sữa & Cầu & - \\
\hline Cửa sông Gia Minh & GMDa & $\begin{array}{c}\text { Khuẩn lạc tròn, màu đỏ, tế bào dễ } \\
\text { tách }\end{array}$ & Que & - \\
\hline RNM Phù Long & PLTa & Khuẩn lạc tròn, màu đỏ & Que & - \\
\hline RNM Phù Long & PLTb' & $\begin{array}{c}\text { Khuẩn lạc tròn, màu vàng nhạt, bề } \\
\text { mặt nhẵn }\end{array}$ & Que & - \\
\hline RNM Vinh Quang & VQT & $\begin{array}{l}\text { Khuẩn lạc tròn, } \mathrm{d}=2-3 \mathrm{~cm} \text {, màu da } \\
\text { cam, bề mặt nhẵn }\end{array}$ & Cầu & - \\
\hline RNM Tràng Cát & STCK6.22 & $\begin{array}{l}\text { Màu nâu lan toả, mép không đều, dễ } \\
\text { tách, không thay đổi màu dưới các } \\
\text { môi trường khác nhau và không hoà } \\
\text { tan vào môi trường thạch }\end{array}$ & Que & + \\
\hline RNM Tràng Cát & STCV3.13 & Khuẩn lạc màu nâu đất đến vàng nhạt & Que & - \\
\hline RNM Tràng Cát & STCV3.10 & $\begin{array}{c}\text { Khuẩn màu lẫn đất có sắc tố hoà tan } \\
\text { tiết vào môi trường thạch }\end{array}$ & Que & - \\
\hline RNM Tràng Cát & STCM3.29 & $\begin{array}{l}\text { Khuẩn lạc to, mép tròn không đều, bề } \\
\text { mặt hơi lồi, màu vàng nhạt }\end{array}$ & Que & + \\
\hline RNM Tràng Cát & WTCV1.25 & $\begin{array}{l}\text { Màu da cam to lan toả mép không } \\
\text { đều, bề mặt phẳng, không thay đổi } \\
\text { màu dưới môi trường khác nhau và } \\
\text { không hoa tan vào môi trường thạch }\end{array}$ & Cầu & - \\
\hline RNM Bàng La & SBLV4.15 & $\begin{array}{c}\text { Khuẩn lạc màu nâu đất, có sắc tố hoà } \\
\text { tan tiết vào môi trường thạch }\end{array}$ & Que & - \\
\hline $\begin{array}{c}\text { RNM } \\
\text { Tràng Cát }\end{array}$ & BLV-02 & $\begin{array}{c}\text { Khuẩn lạc màu đỏ, nhỏ, mép tròn } \\
\text { không đều dưới điều kiện kị khí có } \\
\text { chiếu sáng }\end{array}$ & Que & - \\
\hline RNM Bàng La & WBLV2.15 & $\begin{array}{c}\text { Màu nâu đất, có sắc tố hoà tan tiết } \\
\text { vào môi trường thạch }\end{array}$ & Que & - \\
\hline Đất RNM Tràng Cát & STCK99 & $\begin{array}{l}\text { Màu trắng sữa to, không thay đổi } \\
\text { màu dưới môi trường khác nhau và } \\
\text { không hòa tan vào môi trường thạch }\end{array}$ & Que & + \\
\hline
\end{tabular}


Bảng 4: Đặc điểm sinh hoá một số chủng vi khuẩn điển hình

\begin{tabular}{|c|c|c|c|c|c|c|c|c|c|c|c|c|}
\hline 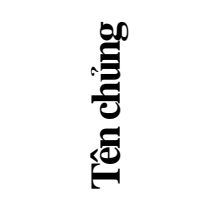 & & 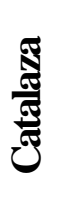 & 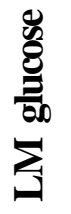 & 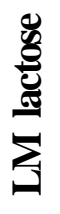 & 总 & 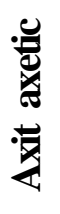 & 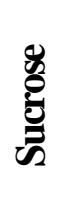 & 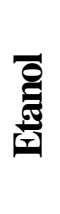 & 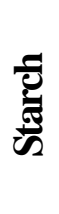 & 倦 & $\frac{\frac{0}{0}}{\frac{\theta}{g}}$ & $\mathcal{F}$ \\
\hline STCM3.27 & Trung hoà & + & - & + & + & - & + & - & - & + & - & - \\
\hline SBLK3.6 & Axit hoá & + & + & + & + & - & + & - & - & + & + & 0 \\
\hline STCK6.22 & Axit hoá & + & + & + & + & + & + & - & + & + & 0 & 0 \\
\hline STCV3.13 & Trung hoà & + & - & + & + & - & + & - & - & - & - & - \\
\hline STCV3.10 & Kiềm hoá & + & - & + & + & - & + & - & - & + & - & 0 \\
\hline STCM3.29 & Axit hoá & + & + & + & + & + & + & - & + & + & 0 & 0 \\
\hline SBLV4.2 & Axit hoá & + & - & + & - & - & - & - & - & + & - & 0 \\
\hline WTCV1.25 & Axit hoá & + & - & + & - & - & + & - & - & + & - & - \\
\hline SBLV4.15 & Kiềm hoá & + & - & + & + & - & + & - & + & - & 0 & 0 \\
\hline STCV3.7 & - & + & - & - & + & - & + & - & - & + & - & 0 \\
\hline BLV-01 & Axit hoá & + & + & + & - & + & + & - & - & - & - & - \\
\hline BLV-02 & Axit hoá & + & + & + & - & + & + & - & - & - & - & - \\
\hline SBLV2-12 & Axit hoá & + & + & + & + & - & + & - & - & - & + & 0 \\
\hline STCK99 & Axit hoá & + & + & + & + & + & + & + & + & + & 0 & 0 \\
\hline WBLV2.15 & Trung hoà & + & - & + & - & - & - & - & - & - & 0 & 0 \\
\hline $1 \mathrm{VK} 3$ & 0 & + & + & + & 0 & 0 & - & + & - & - & 0 & 0 \\
\hline $1 \mathrm{VK} 5$ & 0 & + & + & + & 0 & 0 & - & + & - & - & 0 & 0 \\
\hline $2 \mathrm{VK} 2$ & 0 & + & + & - & 0 & 0 & - & + & - & - & 0 & 0 \\
\hline $2 \mathrm{VK} 5$ & 0 & + & + & - & 0 & 0 & - & + & - & - & 0 & 0 \\
\hline $2 \mathrm{VK} 8$ & 0 & - & - & - & 0 & 0 & - & + & - & - & 0 & 0 \\
\hline $4 \mathrm{VK} 1$ & 0 & + & - & - & 0 & 0 & + & + & - & - & 0 & 0 \\
\hline $4 \mathrm{VK} 2$ & 0 & + & + & - & 0 & 0 & + & - & + & - & 0 & 0 \\
\hline VK07 & 0 & + & + & + & 0 & 0 & + & - & + & + & 0 & 0 \\
\hline 1VK8 & 0 & + & + & + & 0 & 0 & + & + & + & + & 0 & 0 \\
\hline $2 \mathrm{~V} 2$ & 0 & + & + & + & 0 & 0 & + & + & + & + & 0 & 0 \\
\hline $2 \mathrm{~V} 1$ & 0 & + & + & + & 0 & 0 & + & - & + & + & 0 & 0 \\
\hline $2 \mathrm{~V} 8$ & 0 & + & + & + & 0 & 0 & + & + & + & + & 0 & 0 \\
\hline
\end{tabular}

*Ghi chú: (+): duoong tích, (-): âm tính, (0): chua xác định 


\section{5. Đặc điểm sinh hoá}

Các chủng vi khuẩn này cũng được tiến hành phân tích các đặc tính sinh hoá như là khả năng dịch hoá sữa, phản ứng catalaza, lên men glucose, lên men lactose, khả năng đồng hoá các loại đường đơn (mannose, sucrose, etanol, axit axetic .v.v.), khả năng phân huỷ các đại phân tử (tinh bột, gelatine) và một số đặc tính sinh hoá dùng để định loại khác như là nitrat hoá, phản nitrat, sinh indole, khử $\mathrm{H}_{2}$ S.v.v. cũng được sử dụng (bảng 4).

Một số kết quả được trình bày ở bảng 3 cho thấy, tất cả các chủng đều có phản ứng catalaza dương tính, đa số các chủng có khả năng kiềm hoá dung dịch sữa, nhiều chủng có khả năng lên men glucose và lactose, nhiều chủng có khả năng phân huỷ gelatine hơn là tinh bột, có nhiều chủng có thể phát triển được trong môi trường chỉ có etanol làm nguồn cácbon duy nhất.

\section{Phân tích trình tự $16 \mathrm{~S}$ rRNA chủng vi khuẩn VK 07 và STC99}

Trình tự 16S rRNA của chủng vi khuẩn VK07 và STC99 được nhân lên bằng cặp mồi: 5' AGAGTTTGACCTGGCTCAC 3' và 5' CGGCTACCTTGTTACGACTT 3' tại nhiệt độ gắn mồi là $\mathrm{Ta} 54^{\circ} \mathrm{C}$, sau khi tinh sạch sản phẩm này được phân tích trình tự trên máy phân tích DNA.

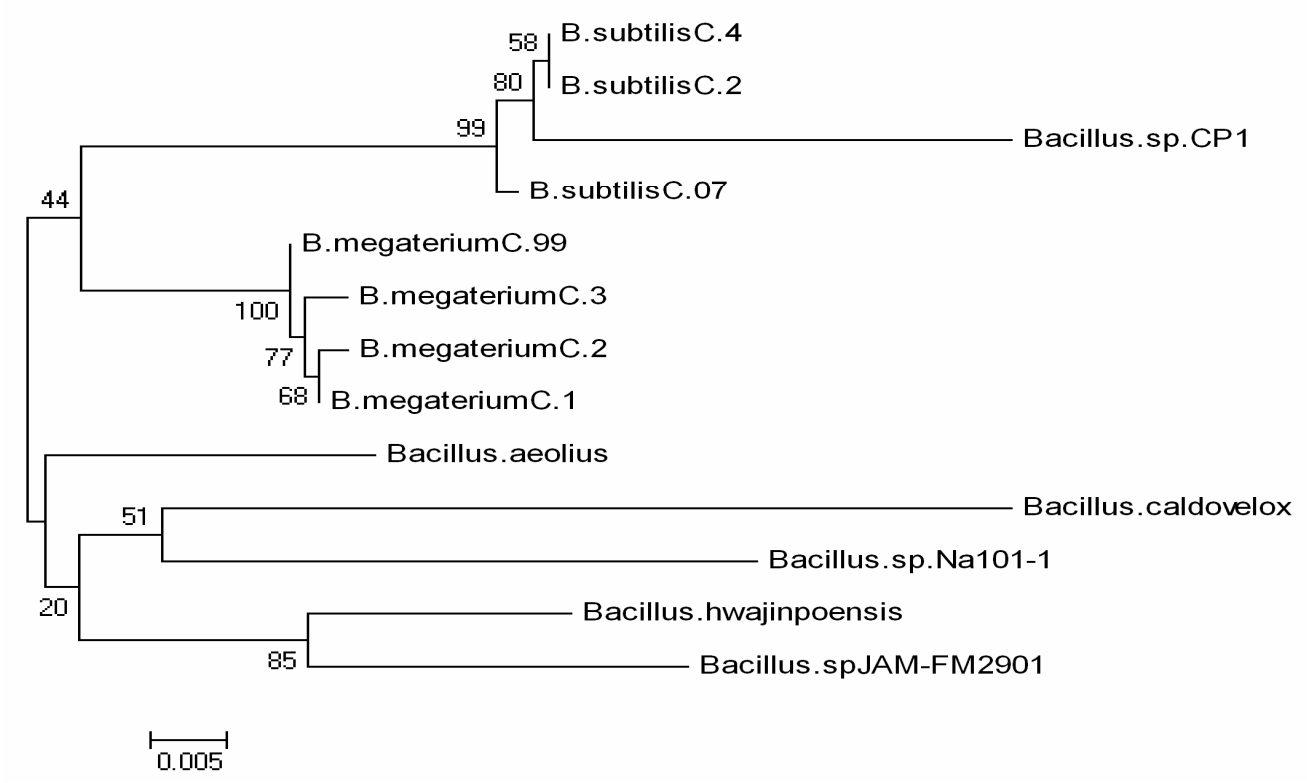

Hình 4: Cây phát sinh chủng loại của chủng

Cây phát sinh chủng loại của 2 chủng vi khuẩn này với các loài vi khuẩn có mối quan hệ di truyền gần gũi được xây dựng bằng phần mềm MEGA 4.0 (Kumar et al., 
2006). Kết quả trong hình 4 cho thấy chủng VK07 thuộc loài Bacillus subtilis và có mối liên hệ gần gũi với loài Bacillus subtilis C.2, Bacillus subtilis C.4 và Bacillus sp. CP1, chủng STC99 thuộc loài Bacillus megaterium và có mối quan hệ gần gũi với loài Bacillus megaterium C.3.

\section{Hoạt tính một số chủng vi khuẩn ven biển Hải Phòng}

\subsection{Hoạt tính nitrat hoá}

Sau thời gian 42 ngày nuôi vi khuẩn oxy hoá amon trong bể thuỷ tinh thứ nhất dung tích 201 , nồng độ amon từ 45,86 mg/l giảm xuống còn $0,12 \mathrm{mg} / \mathrm{l}$, tức là chỉ bằng $0,26 \%$ so với nồng độ ban đầu (bảng 5). Từ hình 5 cho thấy nồng độ amon giảm mạnh nhất trong 22 ngày đầu, từ $45,86 \mathrm{mg} / \mathrm{l}$ xuống còn $4,01 \mathrm{mg} / \mathrm{l}$, chỉ bằng $8,7 \%$ so với nồng độ ban đầu. Nồng độ nitrit từ $0,052 \mathrm{mg} / \mathrm{l}$ sau 42 ngày nuôi giảm xuống còn $0,013 \mathrm{mg} / \mathrm{l}$, bằng $25 \%$ nồng độ ban đầu.
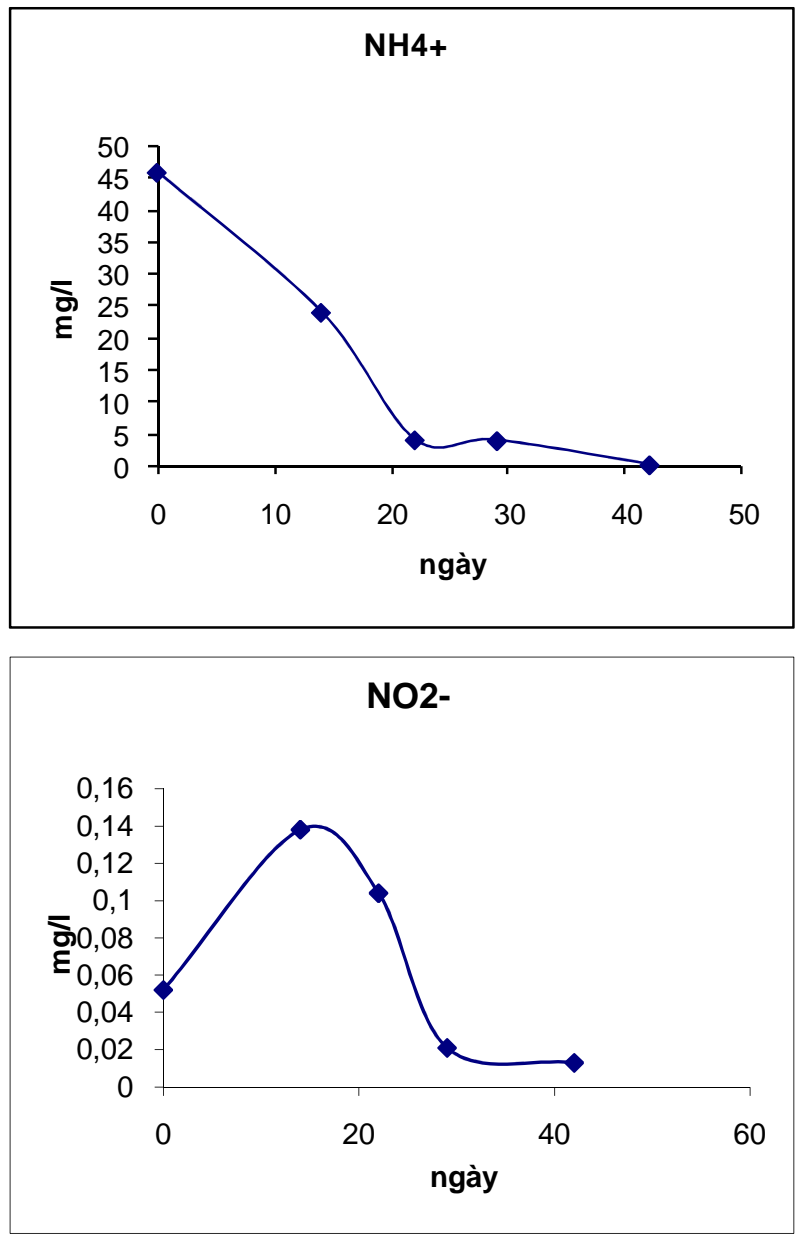

Hình 5: Hoạt tính nitrat hoá trong các bể thuỷ tinh thí nghiệm 
Bảng 5: Kết quả đo hoạt tính nitrat hoá trong các bể thuỷ tinh thí nghiệm

\begin{tabular}{|c|c|c|c|c|c|c|}
\hline \multirow{2}{*}{ STT } & \multirow{2}{*}{$\begin{array}{c}\text { Hoá chất } \\
(\mathbf{m g} / \mathbf{l})\end{array}$} & \multicolumn{5}{|c|}{ Thời gian đo hoạt tính (ngày) } \\
\cline { 3 - 7 } & & $\mathbf{0}$ & $\mathbf{1 4}$ & $\mathbf{2 2}$ & $\mathbf{2 9}$ & $\mathbf{4 2}$ \\
\hline Bể 01 & $\mathrm{NH}_{4}^{+}$ & 45,86 & 23,98 & 4.01 & 3,88 & 0,12 \\
\hline Bể 02 & $\mathrm{NO}_{2}^{-}$ & 0,052 & 0,138 & 0,104 & 0,021 & 0,013 \\
\hline
\end{tabular}

\subsection{Hoạt tính phân giải protein, tinh bột và phản nitrat hoá}

Tám chủng vi khuẩn được phân lập từ đầm nuôi trồng thuỷ sản Kiến Thuỵ và Đồ Sơn được tiến hành phân tích khả năng phân giải protein, tinh bột và phản nitrat. Kết quả trong bảng 6 cho thấy, ba chủng KT001, KT003 và DS003 có cả ba hoạt tính phân giải protein, tinh bột và phản nitrat, trong đó KT001 và KT003 có hoạt tính phân giải protein và tinh bột mạnh.

\subsection{Khả năng đối kháng đối với Vibrio}

13 chủng vi khuẩn phân lập vùng ven biển Hải phòng được tiến hành phân tích khả năng đề kháng hai chủng vi khuẩn gây bệnh Vibrio parahaemolyticus và Vibrio fuonissi. Kết quả bảng 7 cho thấy, 9 chủng có khả năng đối kháng với Vibrio parahaemolyticus và chín chủng có khả năng đối kháng với $V$. fuonissi. Đáng chú ý là các chủng B1H6, L1H3, B1H5 và DS002 có khả năng ức chế cả 2 loài Vibrio cao.

\subsection{Kết quả thử nghiệm chế phẩm HIO dạng lỏng và bột vào việc xử lý nước thải nuôi tôm ở quy mô phòng thí nghiệm}

Hai loại nước thải là nước thải đầm nuôi trồng thuỷ sản thuộc địa bàn huyện Kiến Thuỵ (NTKT) và địa bàn thị xã Đồ Sơn (NTDS) sau khi được đưa vào bể thuỷ tinh với lượng thể tích như nhau 10 lít. Các bể kiểm tra sẽ được bổ sung $30 \mathrm{~g}$ chế phẩm/10 $\mathrm{m}^{3}$ nước đối với chế phẩm dạng bột và 01 lít chế phẩm $/ 1000 \mathrm{~m}^{3}$ nước đối với chế phẩm dạng lỏng.

Sau 10 ngày thả chế phẩm, kết quả phân tích mẫu được trình bày ở bảng 8 cho thấy cả hai chế phẩm có tác dụng cải thiện môi trường nước thải đầm nuôi trồng thuỷ sản Kiến thuỵ và Đồ sơn khá tốt, chế phẩm HIO dạng bột tỏ ta có tác dụng cải thị̂n môi trường nước tốt hơn. 
Bảng 6: Hoạt tính phân giải protein, tinh bột và phản nitrat hoá một số chủng vi khuẩn

\begin{tabular}{|c|c|c|c|c|l|}
\hline STT & $\begin{array}{c}\text { Chủng } \\
\text { VK }\end{array}$ & $\begin{array}{c}\text { Phân giải } \\
\text { protein }\end{array}$ & $\begin{array}{c}\text { Phản } \\
\text { nitrat }\end{array}$ & $\begin{array}{c}\text { Phân giải Tinh } \\
\text { bột }\end{array}$ & \multicolumn{1}{|c|}{ Tên loài VK } \\
\hline 1 & KT001 & +++ & + & +++ & $\begin{array}{l}\text { Bacillus } \\
\text { lichenliformis }\end{array}$ \\
\hline 2 & KT002 & + & - & ++ & Lactobacillus sp. \\
\hline 3 & KT003 & +++ & + & +++ & Bacillus cereus \\
\hline 4 & DS001 & ++ & - & ++ & Bacillus subtilis \\
\hline 5 & DS002 & ++ & - & + & Lactobacillus sp. \\
\hline 6 & DS003 & + & + & + & Bacillus sp. \\
\hline
\end{tabular}

*Ghi chú: $(+++)$ : hoạt tính mạnh, (++): ht trung bình, (+): ht yếu, (-): không hoạt tính

Bảng 7: Khả năng ức chế Vibrio của một số chủng vi khuẩn ven biển Hải Phòng

\begin{tabular}{|c|c|c|l|}
\hline \multirow{2}{*}{ Chủng } & \multicolumn{2}{|c|}{ Đối kháng } & \multirow{2}{*}{ Tên loài vi khuẩn } \\
\cline { 2 - 3 } & V.p & V.f & \\
\hline B5H5 & + & - & Bacillus cereus \\
\hline B1H4 & + & + & B. alvei \\
\hline B5H10 & - & + & B. Polymyxa \\
\hline B1H6 & ++ & ++ & B. licheniformis \\
\hline B7H3 & - & - & B. subtillis \\
\hline L1H3 & ++ & ++ & Lactobacillus sp. \\
\hline B1H5 & ++ & ++ & B. licheniformis \\
\hline KT001 & + & + & Bacillus lichenliformis \\
\hline KT002 & + & + & Lactobacillus sp. \\
\hline KT003 & - & + & Bacillus cereus \\
\hline DS001 & + & - & Bacillus subtilis \\
\hline DS002 & ++ & ++ & Lactobacillus sp. \\
\hline DS003 & - & - & Bacillus sp. \\
\hline
\end{tabular}

Ghi chí: V.p: Vibrio parahaemolyticus, V.f: Vibrio fuonissi 
Bảng 8: Thông số hoá lý trong nước thải nuôi trồng thuỷ sản sau 10 ngày thả chế phẩm

\begin{tabular}{|c|c|c|c|c|c|c|}
\hline \multirow{2}{*}{ Thông số } & \multicolumn{3}{|c|}{ Nước thải NTTS Kiến Thuy. } & \multicolumn{3}{|c|}{ Nước thải NTTS Đồ Sơn } \\
\cline { 2 - 7 } & Bột & Lỏng & DC & Bột & Lỏng & DC \\
\hline $\mathrm{T}^{0} \mathrm{C}$ & 30 & 30 & 30 & 30 & 30 & 30 \\
\hline $\mathrm{pH}$ & 7,6 & 7,5 & 7,32 & 7,65 & 7,60 & 7,50 \\
\hline $\mathrm{DO}(\mathrm{mg} / \mathrm{l})$ & 5,5 & 5,0 & 4,5 & 4,6 & 4,5 & 4,3 \\
\hline $\mathrm{BOD}_{5}(\mathrm{mg} / \mathrm{l})$ & 2,2 & 3,0 & 4,8 & 3,9 & 4,0 & 4,3 \\
\hline $\mathrm{COD}^{2}(\mathrm{mg} / \mathrm{l})$ & 15,5 & 15,9 & 16,7 & 14,5 & 14,7 & 15,0 \\
\hline $\mathrm{NH}_{4}{ }^{+}(\mathrm{mg} / \mathrm{l})$ & 0,13 & 0,14 & 0,20 & 0,14 & 0,15 & 0,17 \\
\hline
\end{tabular}

\section{KẾT LUẬN}

Chúng tôi đã xác định được 31 loài vi khuẩn thuộc 16 chi, 8 họ và 2 bộ cho vùng ven biển Hải Phòng. Vi khuẩn kiếu khí, xạ khuẩn, nấm men và nấm sợi thường có mật độ cao vào mùa mưa và thấp vào mùa khô, số lượng vi khuẩn hiếu khí và xạ khuẩn trong các mẫu trầm tích thường cao hơn mẫu nước bề mặt từ 10 - 100 lần, nhưng nấm sợi và nấm men lại có xu hướng ngược lại.

Nhiều chủng vi khuẩn có hoạt tính nitrat hoá, phản nitrat, phân giải protein, tinh bột và khả năng đối kháng với vi khuẩn gây bệnh cao. Chế phẩm dạng lỏng và bột được tạo ra từ tổ hợp một số chủng vi khuẩn có các hoạt tính cao này khi kiểm tra trên nước thải đầm

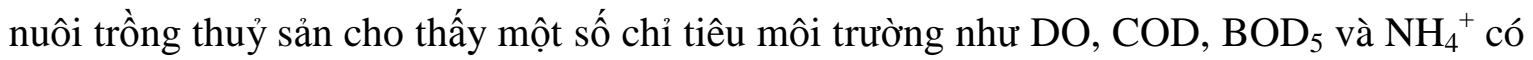
sự cải thiện đáng kể so với mẫu đối chứng sau 10 ngày thử nghiệm.

\section{TÀI LIỆU THAM KHẢO}

1. Nguyễn Lân Dũng, Đoàn Xuân Mượu, Nguyễn Phùng Tiến, Đặng Đức Trạch, Phạm Văn Ty, 1972-1978. Một số phương pháp nghiên cứu vi sinh vật tập I, II, III. NXB. KH \& KT Hà Nội, 471Tr., 430Tr., 441Tr.

2. Lại Thuý Hiền, Đặng Phương Nga, Đỗ Thu Phương, Phạm Thị Hằng, Kiều Quỳnh Hoa, Vương Thị Nga, Nguyễn Thị Yến, Nguyễn Bá Tú, 2008. Một số kết quả nghiên cứu đa dạng vi sinh vật tại biển đảo Cát Bà. Hội nghị khoa học toàn Quốc về sinh thái và tài nguyên sinh vật lần thứ hai: 284-293. 
3. Đỗ Mạnh Hào, Đàm Đức Tiến, 2003. Bước đầu nghiên cứu nhóm vi khuẩn nitrat hoá trong đầm nuôi trồng thuỷ sản Hải Phòng. Đề tài cơ sơ Viện Tài nguyên và Môi trường biển, 57 tr.

4. Đỗ Mạnh Hào, Đàm Đức Tiến, 2004. Bước đầu nghiên cứu nhóm vi khuẩn phân giải protein, tinh bột và phản nitrat hoá vùng ven biển Hải Phòng. Báo cáo đề tài cơ sở 2004, 40tr.

5. Đỗ Mạnh Hào, 2005. Nghiên cứu thử nghiệm sản xuất chế phẩm xử lý nước thải đầm nuôi trồng thuỷ sản. Báo cáo đề tài cơ sở 2005, 50tr.

6. Đỗ Mạnh Hào, Phạm Thế Thư, 2007. Ửng dụng phương pháp giải trình tự gen $16 \mathrm{~S}$ rRNA vào việc phân loại một số chủng vi khuẩn rừng ngập mặn Bàng La, Tràng Cát. Báo cáo đề tài cơ sở 2007, 49tr.

7. Hao Do Manh, Matsuo Yoshihide, Atsuko Katsuta, Satoru Matsuda, Yoshikazu. Shizuri and Hiroaki Kasai, 2008. Robiginitalea myxolifaciens sp. nov., a novel myxol-producing bacterium isolated from marine sediment and emended description of the genus Robiginitalea. International Journal of Systematic and Evolutionary Microbiology 58: 1660-1664.

8. Trần Đức Thạnh, Nguyễn Đức Cự, Nguyễn Chu Hồi, 1993. Báo cáo môi trường địa chất ven bờ Hải phòng. Thư viện Phân viện Hải dương học Hải phòng. 151 Tr.

9. Breed Robert, S.; Murray, E.G.D.; Smith Nathan, R., 1957. Bergey's manual determinative bacteriology, seventh edition. London, Bailiere. Tindall \& Cox, Ltd. USA. 1094p.

10. Smibert, R. M., \& Krieg, N. R., 1994. Phenotypic characterization. In Methods for General and Molecular Bacteriology, pp. 607-654. Edited by P. Gerhardt, R. G. E. Murray, W. A. Wood \& N. R. Krieg. Washington, DC: American Society for Microbiology.

\title{
SOME RESULTS OF STUDY ON MICROBE IN HAI PHONG COASTAL ZONE
}

\author{
DO MANH HAO, PHAM THE THU
}

\footnotetext{
Summary: From 50 water and sediment samples collected in coastal zone of Haiphong, we have isolated 65 bacterial strains and identification belong to 31 species, 16 gena, 8 families and 2 orders, the genus Bacillus, there are the highest species number - 8 species, Pseudomonas being 5 species and the other genus has only 1 - 2 species. Aerobic bacterial amounts in Bang la, Trang cat mangrove are quite high, range of $10^{4}-10^{7} \mathrm{tb} / \mathrm{ml}, \mathrm{g}$; Actinomycetes is $0-10^{2} \mathrm{tb} / \mathrm{ml}, \mathrm{g}$; yeast is $0-2.10^{2} \mathrm{tb} / \mathrm{ml}, \mathrm{g}$ and fungi density can reach up
} 
$10^{3} \mathrm{tb} / \mathrm{ml}, \mathrm{g}$. The number of aerobic bacteria and actinomycetes in sediment samples were higher 10 - 100 times than those in water samples, but the numbers of yeast and fungi were opposite orientation, especially in raining season. Many bacterial strains were tested the ability of nitrifying, denitrifying, degradation of protein, starch and resistibility to pathogens of Vibrio parahaemolyticus and Vibrio fuonissi indicated that had high activities. Liquid and powder probiotics made from a the bacterial combination were evaluated in the wastewater of shrimp aquaculture pond indicating that analysed chemical parameters of DO, COD, BOD and $\mathrm{NH}_{4}^{+}$significantly approved in comparation with control samples in 10 days.

Ngày nhận bài: 05 - 7 - 2009

Ngưòi nhận xét: TS. Đàm Đức Tiến 